\title{
ヒドロキシナフトールブルーを用いたフローインジェクション 分析によるカルシウムの定量
}

\author{
内田 和秀®，友田 正子，斎藤 真一*
}

(1985 年 3 月 27 日受理)

\begin{abstract}
発色削にヒドロキシナフトールブルー（HNB）を用い，フローインジェクション分析 (FIA) を導入 した吸光光度法による, マグネシウムのマスキング剂を使用しないカルシウムの迅速, 簡便な定量法を 開発した. HNB 溶夜 $\left(9.6 \times 10^{-5} \mathrm{~mol} \mathrm{dm}^{-3}\right)$, 水酸化カリウム溶液 $\left(0.6 \mathrm{~mol} \mathrm{dm}^{-3}\right)$ はそれぞれボン ブで送液され，合流後混合コイル中で混合される。試料 $\left(50 \mathrm{~mm}^{3}\right)$ はこの混合試薬溶液に注入され， 反応コイル中を流れて行く過程で発色反応が進行し, $455 \mathrm{~nm}$ の吸光度変化が測定記録される. 本法に よれば $1.2 \sim 3.9 \mathrm{mg} \mathrm{dm}^{-3}$ の範囲で検量線は直線を示し, 試料処理能力は約 40 試料/時間, 相対標準 偏差は $1.12 \%(n=15)$ で繰り返し精度は良好であり操作は極めて簡単である.
\end{abstract}

\section{1 緒 言}

血清中, 食品中, 水道水及び天然水中のカルシウムの 定量はいずれの場合も，単位時間当たり多くの試料数を 処理しなければならない，日本工業規格 (JIS) に定める カルシウム定量法 ${ }^{122}$ は NN 指示薬(3)を用いる EDTA 滴定法及び原子吸光法である. 滴定法は試料処理能力が 低く, 原子吸光法は燃料ガスの取り扱いが多少めんどう である5 . 高い試料処理能力が必要とされている臨床分 析の分野で広く用いられているオートアナライザー（吸 光光度法）にも幾つかの問題点が指摘されている6 .7 ローインジェクション分析 (FIA) では一般に操作の簡 易化，分析の迅速化及び測定者間誤差がないことが特長 である. 又反応生成物が不安定な反応でも時間といらフ アクターを流量及び流路により制御でき応用可能であ る7).

オートアナライザーで広く使用されている 0 -クレン゙ ールフタレインコンプレキソン $(o-\mathrm{CPC})^{8)}$ 10) は, カル シウムに対する優れた発色刻であり，FIA に用いた報 告11) 13) もあるがマグネシウムの妨害に対して，8-キ， リノールなどのマスキング剤を使用しなければならな い. 又使用 $\mathrm{pH}$ 範囲が比較的狭く, 緩衝液の使用が必要 であることが指摘されている14).外飞間接定量法に打い て亜鉛ーグリコールェーテルジアミンテトラ酶酸を用い

* 上智大学理工学部一般科学研究室 : 102 東京都千 代田区紀尾井町 7-1
た報告があるが， $\mathrm{pH}$ を正確に制御する必要があり，亜 鈆の妨害に対しては前処理をしなければならない15).

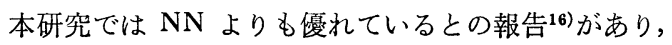
又生体試料 ${ }^{17) 18)}$, 薬剤中19)のカルシウム定量に広く用い られているビドロキシナフトールブルー $(\mathrm{HNB})^{3) 20) を ~}$ 発色剂に用いた. HNB は NN と同様にジヒドロキシ アゾ色素群に属する指示薬で, 高 $\mathrm{pH}$ で使用可能である ので，妨害金属のマグネシウムは水酸化マグネシウムを 生成し, カルシウム-HNB キレート生成を妨害しない。 また $o$-CPC に比較して広い $\mathrm{pH}$ 領域で使用すること が可能である. 更に試料の $\mathrm{pH}$ が $\mathrm{HNB}$ の使用領域外 でも, FIA では試料が試薬によって希釈された状態で反 応するので緩衝液を必要としない. HNB を発色剂に用 いた FIA システムを導入した吸光光度法によるカルシ ウムの迅速, 簡便な直接定量法を開発したので報告する.

\section{2 実験}

\section{$2 \cdot 1$ 試 薬}

金属標準液：カルシウム，マグネシウム，フルミニウ ム, ニッケル, 亜鉛, カドミウム, ストロンチウム, バ リウム，鉄，マンガン及び銅標準液 $(1000 \mathrm{mg} \mathrm{dm}-3)$ は和光純薬工業製原子吸光分析用標準液を蒸留水で適当 に希䣋して用いた。

HNB 溶液 $\left(2.4 \times 10^{-3} \mathrm{~mol} \mathrm{dm}^{-3}\right)$ : 同仁化学研究所 製 HNB $0.745 \mathrm{~g}$ を蒸留水に溶解し, 全容を蒸留水で $500 \mathrm{~cm}^{3}$ とした.

グリセリン溶液 $(50 \mathrm{v} / \mathrm{v} \%)$ : 和光純薬工業製特級グリ セリン $500 \mathrm{~cm}^{3}$ を蒸留水で希釈し, 全容を $1000 \mathrm{~cm}^{3}$ と 
した後褐色瓶に移し保存した。グリセリンは酸化防止剤 として以下の各溶液に添加した.

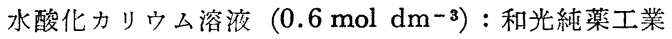
製特級水酸化力リウム $39.6 \mathrm{~g}$ を蒸留水に溶解し, $50 \mathrm{v} / \mathrm{v}$ $\%$ グリセリン溶液を $40 \mathrm{~cm}^{3}$ 加え，全容を蒸留水で 1000 $\mathrm{cm}^{3}$ とした。

分析に際しては上述の HNB 溶液 $40 \mathrm{~cm}^{3}$ 及び $50 \mathrm{v} / \mathrm{v}$ $\%$ グリセリン溶液 $40 \mathrm{~cm}^{3}$ を混合し, 全容を蒸留水で $1000 \mathrm{~cm}^{3}$ としたものを使用直前に調製して $9.6 \times 10^{-5}$ mol $\mathrm{dm}^{-3} \mathrm{HNB}$ 溶液とした.

\section{2 装 置}

ポンプ : Gilson 社製 Minipuls-2 型ペリスタ式ボンプ を用いた：ホンンブチューブは専用の塩化ビニル製のもの を使用した。

サンプルインジェクター：応用分光製六方バルブルー プ式インジェクター(容量 $50 \mathrm{~mm}^{3}$ ) を用いた.

分光光度計：日本分光製 UVDEG-340 型分光光度計 に FIC-361 型フローセル（光路長 $10 \mathrm{~mm}$, 容量 20 $\mathrm{mm}^{3}$ ) を取り付けて使用した.

記録計：理研電子製 SP-G12 型記録計を使用した。

\section{3 実験方法}

種々の検討結果をもとに組み立てた FIA システムの フローダイアグラムを Fig. 1 に示す. ポソプチューブ 以外のチューブ及びュネクターはすべてテフロン製のも のを用いた。流量は操作ごとにポンプを微調整し, 吸 入量を各流路別に 測定して正確に決めた。試料はサン プルインジェクター（S）に樹脂製注射筒 $10 \mathrm{~cm}^{3}$ を用 い,コンタミネーションを避けるため約 $3 \mathrm{~cm}^{3}$ を注入し た $\left(2 \mathrm{~cm}^{3}\right.$ に試料を減らしてもピーク高さに影響はなか った). ポンプ（P) により送液された試薬溶液（B) 及 び $(\mathrm{R})$ は混合コイル $\left(\mathrm{M}_{1}\right)$ 中で混合され, 注入された 試料と反応コイル $\left(\mathrm{M}_{2}\right)$ 中で発色反応が進行する. 反応 生成物は連続的な溶液の流れにより分光光度計のフロー セルを通過し，455 nm に拈ける吸光度変化が測定記録

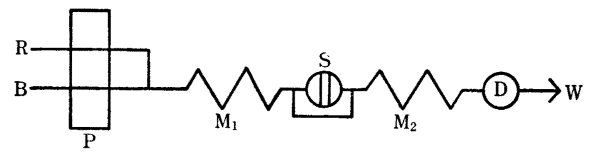

Fig. 1 Flow diagram for the determination of calcium

The optimum conditions were R : HNB $\left(9.6 \times 10^{-5} \mathrm{~mol}\right.$ $\left.\mathrm{dm}^{-3}\right) ; \quad \mathrm{B}: \mathrm{KOH}\left(0.6 \mathrm{~mol} \mathrm{dm} \mathrm{dm}^{-3}\right) ; \mathrm{M}_{1}$ : mixing coil (1.0 mm i. d., $8 \mathrm{~m}$ long); $\mathrm{S}:$ sample injector (sample volume, $\left.50 \mathrm{~mm}^{3}\right) ; \quad \mathrm{M}_{2}$ : reaction coil $(1.0 \mathrm{~mm}$ i. d., $1.5 \mathrm{~m}$ long plus $0.5 \mathrm{~mm}$ i. d., $0.9 \mathrm{~m}$ long); $\mathrm{D}:$ detector (spectrophotometer, wavelength $455 \mathrm{~nm}$ ); W : waste; $\mathrm{P}$ : pump. Flow rate $(\mathrm{R}$ and $\mathrm{B}): 1.4 \mathrm{~cm}^{3}$ $\min ^{-1}$
される．記録されたピーク高さを吸光度に換算し，あら かじめ求めて打いた検量線を用い，カルシウム濃度を決 定した. 天然水は孔径 $20 \sim 30 \mu \mathrm{m}$ のガラスフィルター により沪過した後, 水道水は直接蒸留水で 10 倍に希勫 し測定試料とした. 試料濃度が高く検量線の直線範囲を 越える場合は希釈倍率を上げた。

\section{3 結果及び考察}

\subsection{HNB の酸化分解}

本研究を行らに当たり, 単一流路の FIA システムを 使用し，あらかじめ調製した HNB-水酸化カリウム混 合溶液を流して測定するとべースラインが徐々に吸光度 の減少する方向へずれていき，測定ピークに悪影響を及 ぼし，定量に負の䛊差を与えた ${ }^{21)}$ 。これは HNB の酸化 による退色と考劣られる。一般にアゾ化合物は酸化によ りアゾキシ化合物 (黄色) になることが知られている22). 青色を示していた廃液は 1 日たつと黄色になった。

本研究では HNB の退色による誤差が定量に影響を及 ぽさないように, Fig. 1 に示した FIA システムを用い た. 水酸化カリウム溶液と HNB 溶液を別々の流路に 流し, 合流点から検出器に至る時間を流量で規定するこ とにより，HNB の分解率を一定にすることが可能であ る.

\subsection{HNB 溶液の濃度}

HNB 溶液の濃度は直接検量線の直線範囲に影響を及 ぼすことが予想される．単一流路の FIA システムにお いて, 2.4 7.2 $\times 10^{-5} \mathrm{~mol} \mathrm{dm}^{-3}$ で HNB 溶液の濃度を 変化させ直線性を検討した結果, $2.4 \times 10^{-5} \mathrm{~mol} \mathrm{dm}^{-3}$ では傾きが低く直線領域も $0.4 \sim 1.2 \mathrm{mg} \mathrm{dm}^{-3}$ と狭かっ た. $4.8 \times 10^{-5} \mathrm{~mol} \mathrm{dm}^{-3}$ では傾きも増加し, 直線領域 は $0.1 \sim 2.6 \mathrm{mg} \mathrm{dm}^{-3}$ と広くなった. $7.2 \times 10^{-5} \mathrm{~mol}$ $\mathrm{dm}^{-3}$ では $4.8 \times 10^{-5} \mathrm{~mol} \mathrm{dm}^{-3}$ に比較し, わずかに傾 きが増し, 直線領域は $0.4 \sim 3.0 \mathrm{mg} \mathrm{dm}^{-3}$ とあまり差は なかった、試薬から試験が高い波長を使用することを考 慮し, $4.8 \times 10^{-5} \mathrm{~mol} \mathrm{dm}^{-3}$ を最適濃度とした。本研究 では水酸化カリウム溶液と HNB 溶液を流路中にて混合 するため, HNB 溶液の希釈を考虑し HNB 溶液濃度を $9.6 \times 10^{-5} \mathrm{~mol} \mathrm{dm}^{-3}$ とした.

\section{3 水酸化カリゥム溶液の濃度と測定波長の検討}

カルシウムに対するマグネシウムの妨害は, pH の調 整と測定波長を変化させることで抑制することが可能で ある. 波長の変化に対する吸光度の変化をカルシウム標 準液と, マグネシウム標準液をカルシウム標準液に添加 
した試料について測定した結果を Fig. 2 に示す. 450 $\mathrm{nm}$ 付近で両試料の曲線は交差した. 水酸化カリウムの 濃度を $0.3 \sim 0.7 \mathrm{~mol} \mathrm{dm}^{-3}$ の間で変化させた結果, 0.3 $0.6 \mathrm{~mol} \mathrm{dm}^{-3}$ では濃度が上がるにつれて交点は徐々 に長波長側に移動し， $0.7 \mathrm{~mol} \mathrm{dm}-3$ では逆に 短波長側 に移動した. $450 \mathrm{~nm}$ において 測定したピーク高さは $\mathrm{pH}$ が上がるにつれて減少した. 又交点が比較的長波長 側にあるほらがピーク高さは高かっだ・試薬から試験值 は高いもののマグネシウムの妨害が最小となる 波長は $455 \mathrm{~nm}$ で, 水酸化カリウム溶液の濃度は $0.6 \mathrm{~mol} \mathrm{dm}^{-3}$ であった. な拉，Fig. 2 に示した結果から水酸化マグ ネシウムの生成は類推しえない。

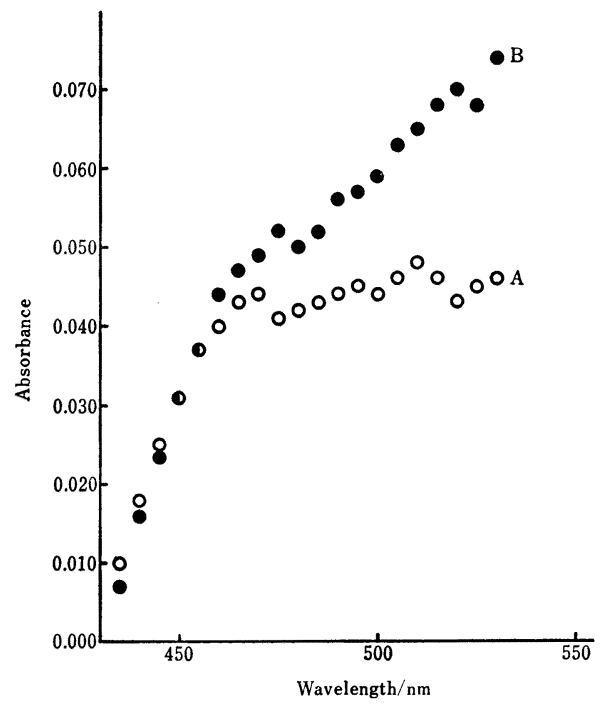

Fig. 2 Absorption spectra

Curve A : calcium standard solution $\left(2 \mathrm{mg} \mathrm{dm}^{-3}\right)$; Gurve B : mixture of calcium $\left(2 \mathrm{mg} \mathrm{dm}^{-3}\right)$ and magnesium $\left(2 \mathrm{mg} \mathrm{dm}^{-3}\right)$; Conditions of FIA system$\mathrm{R}: \mathrm{HNB}\left(9.6 \times 10^{-5} \mathrm{~mol} \mathrm{dm}^{-3}\right), \mathrm{B}: \mathrm{KOH}(0.6 \mathrm{~mol}$ $\left.\mathrm{dm}^{-3}\right), \mathrm{M}_{1}: 8 \mathrm{~m}, \mathrm{M}_{2}: 1.9 \mathrm{~m}$, Flow rate $: 1.2 \mathrm{~cm}^{3}$ $\min ^{-1}, \mathrm{pH} 13.4$

\section{4 フローシステムの検討}

混合コイルの長さは HNB の高 $\mathrm{pH}$ 領域における酸 化による退色を考慮すると短いほど良いが，HNB 溶液 と水酸化カリウム溶液の均一混合を行らにはある程度の 長さが必要となる。不均一な混合はベースラインのドリ フトを誘発し，定量限界及び繰り返し精度に悪影響を及 ぼす．上記の理由により混合コイルの長さを $1 \mathrm{~m}$ ずつ 延長していき，安定なベースラインが得られた $8 \mathrm{~m}$ を 用いた。
反応コイルの長さと流量は FIA における最重要因子 であり，注入する試料の分散に影響する．流量を一定と して反応コイルの長さを変化させ，曲線の傾きと直線性 を検討した結果を Fig. 3 に示す. 反応コイルの長さが 増すにつれて傾きは小さくなり，逆に直線範囲は長くな った.この傾向は流量を $1.0 \sim 2.2 \mathrm{~cm}^{3} \mathrm{~min}^{-1}$ の間で変 化させても変わらなかった。しかし傾きと直線範囲から 導かれるカルシウムの定量範囲と, より良いピーク形状 を示す条件は反応コイルの長さ $2.4 \mathrm{~m}$ であった. 又流 量を増加させると傾きも増大し, $1.4 \mathrm{~cm}^{3} \mathrm{~min}^{-1}$ で最大 となり以後減少した。これは分散で起こる試料の希釈に よる吸光度の減少と, 同じく分散で起こる試料と発色液 の混合による吸光度の増加という二律背反性をもつこと を意味する。

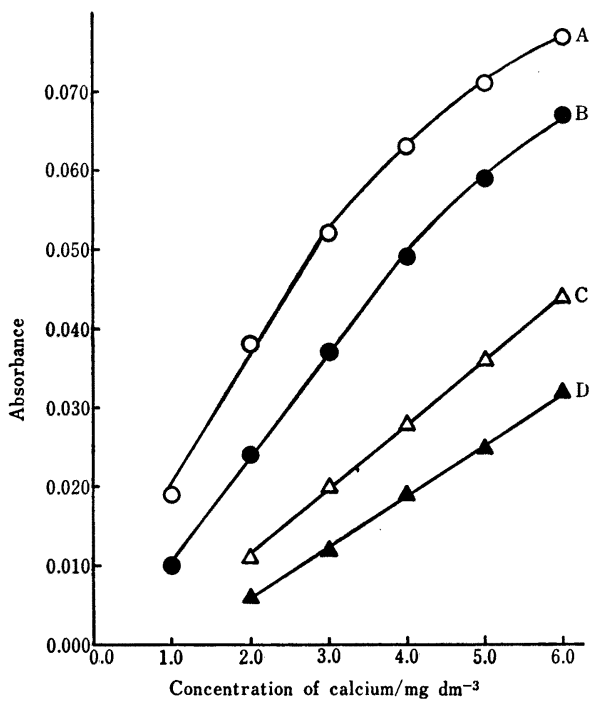

Fig. 3 Influence of the reaction coil length A : $1.9 \mathrm{~m}, \mathrm{~B}: 2.4 \mathrm{~m}, \mathrm{C}: 2.9 \mathrm{~m}, \mathrm{D}: 3.9 \mathrm{~m}$; Flow rate (both $\mathrm{R}$ and $\mathrm{B}$ ) : $1.4 \mathrm{~cm}^{3} \mathrm{~min}^{-1}$

\section{5 妨害金属の検討}

マスキング剂未使用での 各金属の妨害を調べるため に，各金属の濃度に対する吸光度を測定した結果を Fig. 4 に示す. 各金属標準液試料にカルシウム $3 \mathrm{mg}$ $\mathrm{dm}^{-3}$ を添加し, 各金属の濃度系列を調製した. 鉄, マ グネシウム，ストロンチウムはわずかに正の妨害を示す が，カルシウムと同濃度である $3 \mathrm{mg} \mathrm{dm}^{-3}$ 程度では䛊 差は定量限界以下で問題はないと思われる.アルミニゥ ム, 亜鉛, バリウムは $6 \mathrm{mg} \mathrm{dm}^{-3}$ まで全く妨害を示さ なかった.ニッケル及び銅は試薬自体が緑色と青色を有 


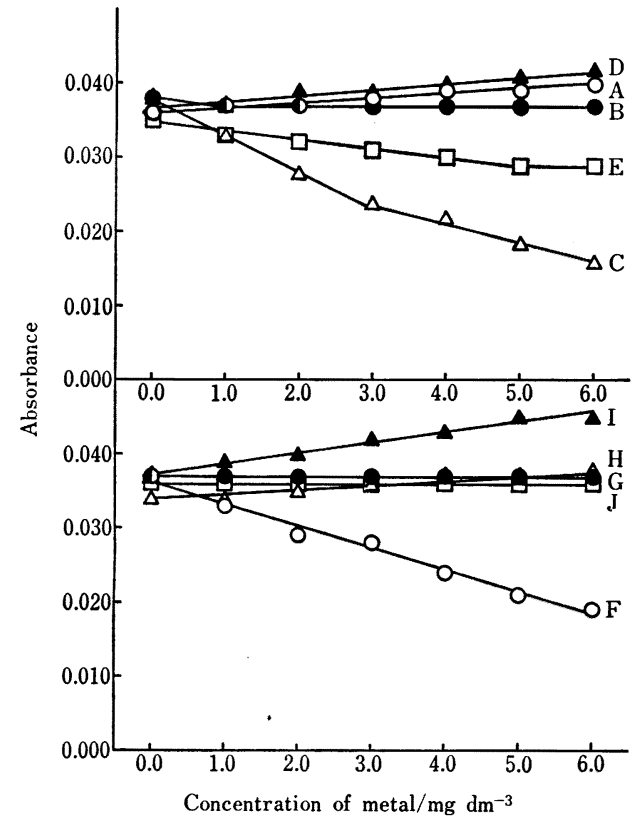

Fig. 4 Effects of foreign metals

Foreign metals were added to the calcium standard solution $\left(3 \mathrm{mg} \mathrm{dm}^{-3}\right) . \quad \mathrm{A}: \mathrm{Mg}, \mathrm{B}: \mathrm{Al}, \mathrm{C}: \mathrm{Mn}, \mathrm{D}$ : Fe, E: Ni, F: Cu, G: Zn, H:Sr, I: Cd, J:Ba

することが，又マンガンは HNB を溶存酸素が酸化する

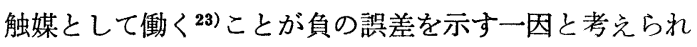
るが，測定波長により大きく影響される。

\section{6 検量線及び応用試料の測定}

Fig. 1 に示したフローダイアグラムの流路を使用 し，最適条件でカルシウム標準液を用いて作成した検量 線を Fig. 5 に示す. 検量線は $1.2 \sim 3.9 \mathrm{mg} \mathrm{dm}^{-3}$ で良 好な直線を示した. 検出限界は $0.6 \mathrm{mg} \mathrm{dm}^{-3}$ であった。 天然水及び水道水中のカルシウムの定量結果を Table 1 亿示す．応用試料はすべて 10 倍希釈し， $\mathrm{pH}$ 調整など の前処理なしに FIA にて測定した。 な打滴定操作は試

Table 1 Determination of calcium in natural and tap waters

\begin{tabular}{ccc}
\hline Sample & $\begin{array}{c}\text { FIA }^{\text {a) }} \\
\mathrm{mg} \mathrm{dm}^{-3}\end{array}$ & $\begin{array}{c}\text { Titration }^{\mathrm{b}} / / \\
\mathrm{mg} \mathrm{dm}^{-3}\end{array}$ \\
\hline Pond of Inokashira & & \\
Park (Tokyo) & 22.8 & 23.0 \\
Tap water (Tokyo) & 25.4 & 25.7 \\
" (Kanagawa) & 20.4 & 20.2 \\
" (Saitama) & 28.2 & 26.7 \\
\hline
\end{tabular}

a) Samples for FIA were diluted ten times with distilled water.

b) The titration was carried out by the JIS method.

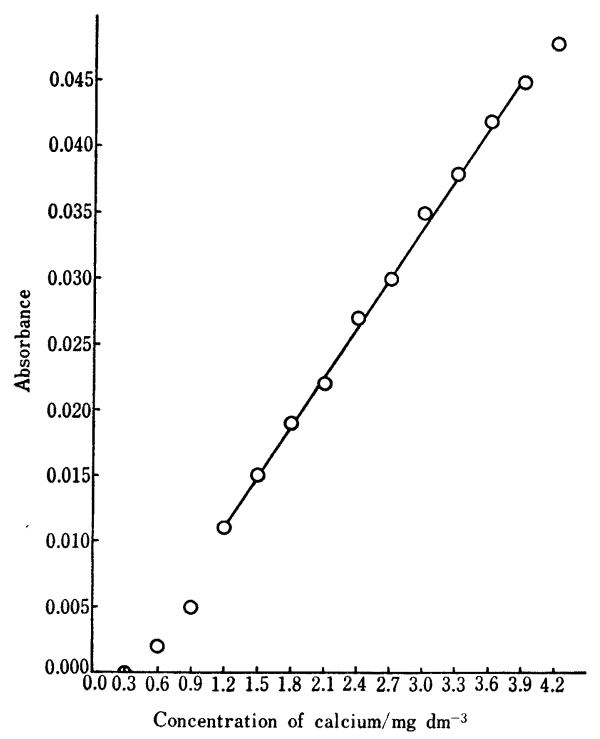

Fig. 5 Calibration curve for calcium

Absorbance was measured under the optimum conditions.

料を希釈せず直接 JIS 法1)2 亿従って行った. FIA の值 と滴定值はほぼ一致した。応用試料に打いて相対標準偏 差 (R.S.D.) は $1.12 \%(n=15)$ で, 試料処理能力は約 40 試料/時間と, 迅速であった.

\section{交献}

1) JIS K0101，工業用水試験方法 (1979).

2）並木 博：“詳解工場排水試験方法”, p. 322 (1982), (日本規格協会).

3) A. Itoh, K. Ueno : Analyst (London), 95, 583 (1970).

4）上野景平：“キレート滴定法”，p. 102 (1979), (南江堂).

5）田中誠之，飯田芳男：“機器分析”, p. 100(1974), (裳華房).

6) 石橋信彦, 与座範政訳：“フローインジェクシ ョン分析法”, p. 11 (1983), (化学同人); \{J. Růžička, E. H. Hansen: "Flow Injection Analysis", (1981), (J. Wiley \& Sons, Inc., New York)\}.

7）上野景平, 喜納兼勇：“フローインジェクション 分析法入門”, p. 3 (1983), (講談社).

8) F. H. Pollard, J. V. Martin : Analyst (London), 81, 348 (1955).

9) H. J. Gitelman : Anal. Biochem., 18, 521 (1967).

10) 浅井孝道：検査と技術，10，31 (1982).

11) E. H. Hansen, J. Růžička, A. K. Ghose : Anal. Chim. Acta, 100, 151 (1978).

12) W. D. Basson, J. F. van Staden : Analyst (London), 103, 296 (1978).

13) W. D. Basson, J. F. van Staden : Analyst (London), 104, 419 (1979).

14）牧野鉄男:ドージンニュース，32,1 (1985),（同 仁化学研究所). 
15) G. Nakagawa, H. Wada, C. Wei : Anal. Chim. Acta., 145, 135 (1983).

16) 伊藤敦子, 上野景平: 分化, 19, 393 (1970).

17) G. Catledge, H. G. Biggs : Clin. Chem., 11, 521 (1965)

18）飯田喜俊, 石倉保彦: 臨床検査, 11, 1069(1967).

19) R. W. Goettsch : J. Pharm. Sci., 54, 317 (1965).

20)上野景平：“キレート滴定法”, p. 104 (1979), (南江堂).

21) 内田和秀, 友田正子, 斎藤真一：日本分析化学会 第 33 年会講演要旨集, p. 560 (1984).

22) 中西香爾, 黑野昌庸, 中平靖弘訳 : “有機化学”, p. 928 (1974)，（東京化学同人); $\{$ R. T. Morrison, R. N. Boyd : "Organic Chemistry", (1966), (Allyn \& Bacon, Inc., Boston)\}.

23)上野景平：“キレート滴定法”, p. 337 (1979), (南江堂).

$$
\text { is }
$$

Determination of calcium by flow injection analysis with Hydroxynaphthol Blue. Kazuhide UcHDA, Masako Tomoda, and Shinichi SArto (General Science Laboratory, Faculty of Science and Engineering, Sophia University, 7-1, Kioi-cho, Ghiyoda-ku, Tokyo 102)

Flow injection analysis is proposed for the rapid and simple determination of calcium in natural and tap waters with spectrophotometric detection. The method is based on the color change reaction between calcium in the sample and indicator at $\mathrm{pH} 13$. The change in the absorbance of Hydroxynaphthol Blue (HNB) owing to the complex formation of HNB with calcium is measured spectrophotometrically at $455 \mathrm{~nm}$, for calcium in the sample. No masking reagent for magnesium is required because magnesium hydroxide forms at high $\mathrm{pH}$. The flow injection system was investigated to obtain the optimum conditions for the following: mixing coil length, reaction coil length, flow rate, $\mathrm{pH}$ and wavelength. The effects when metals were added to the calcium standard solution were examined. Barium, zinc, and aluminium did not interfere at all. Magnesium, strontium, and iron did not interfere in amounts up to the amount of calcium present. Nickel, copper, and manganese gave negative errors, and cadmium gave a positive one. A linear relationship was observed between concentration of calcium (from 1.2 to $3.9 \mathrm{mg} \mathrm{dm}^{-3}$ ) and absorbance. This method allows the analysis of ca. 40 samples per $h$. The relative standard deviation was $1.12 \%(n=15)$. The results for analysis of natural and tap waters agreed well with those obtained by standard EDTA titration with $\mathrm{NN}$ as indicator. For a single analysis the sample volume injected was as little as $50 \mathrm{~mm}^{3}$; no complicated operation is required. When the $\mathrm{pH}$ range of sample is from weak acid to strong base, no buffer solution is required.

(Received March 27, 1985)

\section{Keyword phrases}

flow injection analysis; determination of calcium in tap and natural waters; spectrophotometry with $\mathrm{Hy}$ droxynaphthol Blue. 